\title{
Andrzej Wajda's Duties to the Audience
}

\author{
By Tadeusz Miczka \\ Spring 2000 Issue of KINEMA
}

\section{ANDRZEJ WAJDA'S DUTIES TO THE AUDIENCE (OSCAR 2000)}

You may think about cinema whatever you wish but there is one thing, dear colleagues, that you must not do : to disregard the audience.

Andrzej Wajda's to the students of State Film School in Lodz) ${ }^{(1)}$

WHENEVER the principal values in the post-war Polish cinema are being spoken or written about, Andrzej Wajda and his work are being mentioned long before the names and output of other directors. The complicated history of Polish culture, the national style in art and the never ending conversations of the Polish people about the unjust history and difficult contemporary times are closely tied with Andrzej Wajda. He made a name for himself, first of all, because of his contribution in lifting cinema to the status of an art that speaks about current Polish and international problems. He is the author of an original poetics of "fighting cinema" which struggled for a long time to be recognised in the contemporary culture and was deeply involved in politics. This cinema also took an active role in the discussion, a very widespread one in the second half of the $20^{\text {th }}$ century, on how to measure human freedom. Andrzej Wajda's ambitious films, which have usually been innovative and expressed the author's belief that art can shape reality, have always represented a high degree of intensity on their artistic and semantic levels. They abound in various forms of artistic expression as well as individual and collective existential experience.

It is no wonder that they have usually been met, domestically and internationally, not only with accolades and enthusiasm, but also with prejudice and indignation. The artist has been accused of being anti-Polish, anti-socialist, anti-Semitic, philo-Jewish, extremely aesthetic, blasphemous and trashy. Wajda's films easily overcame the indifference of the audience generating passionate emotions but they were usually criticised by the Polish political authorities or used as propaganda tools in Poland and abroad by groups of ideologically malevolent people. The artist has been able to maintain the state of an increased communicative tension for more than forty years. Also for forty years he has been a moral and professional authority for many Polish people and for many foreigners an authentic symbol of a man changing the outlook of contemporary art (not only cinema) and shaping the knowledge about the mechanisms of history and politics.

It is beyond any doubt that Andrzej Wajda's creative approach has its source in the Young Poland ${ }^{(2)}$ model of art, which he continued in a polemic way, and in the romantic tradition to which he assigned an ancillary role to the idea of regaining the nation's independence. ${ }^{(3)}$ Ten years after the end of World War II, when Wajda, the son of a cavalry officer killed by the Russians in Katy, made his first films. The idea of looking for a variety of ways to freedom was born, under the watchful eye of the censors in a country of the "real socialism" and under the direct influence of Soviet communism. The realisation of this idea in art was limited to a haphazard struggle for human rights, particularly the freedom of speech. Wajda's films are good examples of such efforts.

One has to bear in mind that, until 1989, Polish cinema was under strong political pressure and it could not freely use the ideological model of an independent art, free from national and ideological issues (this was also the situation in the Young Poland period). ${ }^{(4)}$ The film directors who felt duty-bound to speak boldly about the reality around them, elaborated their own, successful or futile, means to communicate with the audience beyond the framework set by the authorities. The most dedicated and talented of them used these means to develop their own creativity, to manifest their opinions and to present the individual aesthetic preferences. Wajda quickly mastered the art of speaking with a free man's voice (this is how Agnieszka Holland, who co-operated with Wajda in the 70s described his films). As early as in the 50s he created his authorial role and his films, made in subsequent decades, found their permanent place in the consciousness of Polish society. On an international scale, they helped to shape the opinion that Wajda's reflections on existence, the philosophy of history and art are his major contributions to the world cinema. ${ }^{(5)}$ 
Film became Wajda's passion in that period of his life when he considered himself first of all a painter. During the war Wajda attended the School of Drawing, Painting and Sculpture in Radom and then, for three years, he was a student of The Academy of Arts in Cracow. In the Academy Wajda developed his artistic sensibility under the influence of Andrzej Wróblewski. This artist, an author of a series of canvas paintings (Rozstrzelanie, The Shooting, 1949 and Ukrzesowienie, Turning into a Chair, 1956) and a legend of Polish post-war art, has been remembered by Wajda as the last of the romantic painters and a protector of young-and-angry artists, a painter who fought courageously against socialist realism in art. Young Wajda also had to face the Stalin's concept of art, culture and public life. After joining the Film School in Lodz he was making his first decisions as a film director and his first aesthetic choices in circumstances which were extremely unfavourable for the development of artistic communication.

Two works, which Wajda realised as a student in 1950, Kiedy ty śpisz, (When You Sleep-- a filming of Tadeusz Kubiak's poems about the jobs being done by the adults in the night in order to secure the normal routine of the day) and Zty Chtopiec (Bad Boy-- a didactic story based on motives from a Anthony Chekhov's short story) prove that the strategy of an agitator, which was then obligatory for all the artists, limited his artistic and linguistic sensibility as well as his visual imagination. The normative poetics of socialist-realism did not permit the author to speak because the political system was the sender of the message and the audience obedient subordinates of the system. A game of appearances was played between the artists and the viewers. What Wajda was trying to do then was to use his limited resources to dismantle the mechanism of stateordained of artistic expressions and invent his "private" strategy of a mild agitator. This gave him a little creative freedom. Certainly, he could not set himself free from the ideological conventions but in his next two films about art he proved that the task of an artist is not limited to justifying the party's right to rule the country.

In Ceramika itżecka (Pottery from Itża, 1951) he applied super-optical transformation of the filmed objects. Pottery shone with the rich shine of the spotlights and received symbolic meaning through the contrast of bright and dark shots or slow and fast camera movements. Wajda presented art as an activity bringing sense to life and work. The documentary of Xawery Dunikowski's workshop titled Ide do stońca (I Am Going to the Sun, 1955) contained even more expressive and emotional elements. The prominent Polish sculptor was experiencing his encounter with socialist-realism but this stage in the artist's biography had no interest for Wajda. The film director paid a tribute to the artist -- a loner with no artistic ancestors. Like Kochanowski, Like Chopin (verses from a poem by Stefan Flukowski, written in 1948, expressed his fascination with the overwhelming power of the sculptor over material. The epilogue of the film contains a visualisation of a metaphor contained in Dunikowski's program work-- Autoportret. Ide ku stońcu (A Self-Portrait. I am going to the Sun). In the film the aged artist slowly climbs the monumental stone stairs located in a natural landscape, almost "reaching the stars". The moment he reached the top of the stairs the camera was opens onto a wide landscape filled with blocks of stone, a real "forest of sculptures". The images are accompanied by the words of the author of Brzemienne kobiety (Pregnant Women): "A man in the yoke of life, a man in the service of life, I am going to the Sun, looking for the mysteries of existence in an inspiration which gives birth to our awareness, in the game of creative forces, I am looking for the mystery of existence in conception, in a pregnant woman, in a new life."

Nevertheless, to bid a farewell to socialist-realism, was not an easy thing for Wajda. As a young director he continued his game till 1956. He was the co-author of the screenplay of a propaganda film Trzy opowieśći (Three Stories - 1953). He was still continuing the game when he made Pokolenie (A Generation, 1954), his first feature.

This adaptation of Bohdan Czeszko's novel, A Generation was biased in its plot (the activities of socialist resistance being overvalued) and full of Stalinist newspeak (mastered by Sekuła, the communist hero who organises the underground). Nevertheless the adaptation was somewhat ambiguous. Wajda showed, in a slightly Neorealist manner, the dirty corners of the city, barracks and rubbish heaps where boys played their "war games" and seldom became heroes or communists. The process of psychological maturing of young people was shown in an expressive manner using innovative acting, camera techniques and art design.

Jerzy Lipmann filmed some of the characters from a window through a bottle, using fisheye lens and a 360-degree camera pan. Sometimes Wajda's heroes reflected beams of light and their eyes were full of tears; 
other times they were on spiral staircases or in the middle of crowds carrying lit lanterns. In this way Wajda went beyond the tenets of socialist-realism. He used the strategy of a mediator, a strategy which was a compromise between the pinnacle of socialist-realism and its descent. The film echoes the high-spirited atmosphere, typical for the intellectual, artistic and political disputes of the period, about the future of Poland, its culture and art. The director did not conceal his aesthetic likes and, in A Generation he revealed a part of the creative program which he was developing. For example, the hopeless situation when Jasio Krone, one of the characters in the film, found himself surrounded by the Germans, is a starting point for Wajda's historical and existential "traps".

First of all, however, A Generation was a film about the generation of artists making their debuts, e.g. Czeszko, Wajda, Lipman and a galaxy of actors such as Tadeusz Łomnicki, Roman Polański or Zbigniew Cybulski. It was a film about the generation that did not take any active part in the war and started their adult life with complexes of "fathers' generation" deepened by the official propaganda. In that period young artists were not allowed to talk about these complexes so they talked about themselves. They enriched as well as modified, as far as the political system permitted, the language and content of the message on the screen. The director introduced some new elements to the process of artistic communication by means of delicate aestheticism stimulating the audience's sensual perception, imagination and confrontation of the patriotic with a romantic approach on the screen. This way the artist endeavoured to establish an authentic link with the audience. Certainly, A Generation could not keep pace with the moods and expectations of the majority of viewers but it helped Wajda to establish a thin link of communication beyond the forms of the official discourse.

The political thaw that began in Poland in 1956 did not bring full freedom in artistic creativity. The authorities revoked socialist-realism but they demanded support from the artists of their ideology and their efforts to make people happy within the "real socialism." Censorship was not as strict as before but it still shaped the character of social communication. Artists from the "generation of sons" could speak freely about the problems of the "generation of fathers" but they were not allowed to solve them the way they wished. This problem was at the bottom of ideological tragedy within the Polish school of film, which Wajda started in 1956 together with other film directors. Polish cinema benefited a lot from this tragedy, which is a historical paradox, because it developed its own innovative and original style. This way it became a real art of high cultural value and witnessed many international successes.

Tadeusz in his description of authorial strategies that dominated the Polish feature film between 1956-1961, proves that Wajda made a contact with the audience using the psychotherapeutic methodology. ${ }^{(6)}$ It is beyond any doubt that the author of $A$ Generation tried, metaphorically speaking, to restore the health of the society of his audience by supplying them with self-knowledge. ${ }^{(7)}$ He was breaking the taboos and revealing the nation's complexes. This was when he made a lively and dynamic contact with his audience, and despite the changes that occurred in the country, he continuing using his strategy. In each subsequent decade he elaborated new forms of film psychotherapy and a critical approach to his previous achievements.

In the period called the Polish school of film Wajda dealt with painful problems of the nation, the complex of the Warsaw Insurrection (the motive of a senseless and futile fight of the citizens of Warsaw against the German occupiers Kanat (Canal, 1957), the complex of the Home Army (the tragedy of Maciek Chełmicki, a member of the underground army fighting against the Germans and then against the communists, Popiót $i$ Diament (Ashes and Diamonds, 1958 ) and the drama of September 1939 (the tragedy of Polish cavalry fighting against the modern German army, Lotna, 1959). Most of Wajda's attention was directed towards the biggest tragedies of the Polish people involved in the complicated events of recent history. Just like many other Polish film directors he treated art as a form of reaction to the problems of society and revealed the factors underlying society's complexes as well as their symptoms. He did not avoid bitterness and pessimism in his films.

The formal and textual principle used by the artist was that of a vicious circle, which took the form of a maze in a Dantean inferno of the insurrection in Canal, the polonaise dance, deeply rooted in the Polish romantic tradition in Ashes and Diamonds and the white horse bringing back the memory of the aristocratic Poland before the war in Lotna. The main feature of his individual style was the degree of density of artistic expression which had not been known in Polish cinema so far. For this reason Wajda's over-aestheticised 
pictures started to cause positive emotions and controversies in Poland and abroad. From the start, his films could easily be misinterpreted.

Aestheticism was based on the activation and mutual penetration of artistic contexts from the outside of the film domain. Undoubtedly, the most important links were those between cinema and literature. All Wajda's films were adaptations of well known and popular contemporary literature. Canal was based on a short story by Jerzy Stefan Stawiński and Lotna on the motives from Wojciech Żukrowski's short story. The artist has remained faithful to the great literature until today. There were just a couple of films based on original scenarios. It is not the process of adaptation itself which is the case, what really counts is the fact that literary tradition has been present in his films. Wajda has always perceived literature as a painter and introduced into cinema symbols, motives and shortcuts that are typical for fine arts. His repertoire of painter's inspirations became very wide very early. ${ }^{(8)}$ The aesthetics of the theatre was another motive which played a major role in Wajda's films. In that period he made a couple of stage productions (which were not thematically connected with his films) ${ }^{(9)}$ and he used his theatrical experience when making films. This may be seen in the behaviour of the actors on screen. It is overemphasised, rhythmical (to follow the music, choreography and declamation) very emotional and even hysterical. In the artist's words: "I made film and theatre in the same manner"(10)

Wajda's films made in the 50s did not follow the poetics of realism, this took place only in the 70s. But he would always use strong effects and surprise with a variety of expressive techniques. At the end of the 80 s it became clear that the filmmaker became devoted to aesthetic abundance, sensual forms, surrealistic deformations and disharmonies. The critics were right to see elements of baroque and metaphysical tensions in his style, e.g. the scenes showing a crucifix turned round with gunshots (Ashes and Diamonds) or a veil hovering in the air among fighting soldiers or a white horse in a palace bedroom. Pierre Pitiot rightly interpreted these and similar scenes when he claimed that Wajda's baroque cinema is burdened with the idea of multiplied death, of agony connected with the vision of the end of culture and society. In Pitiot's opinion the artist turns to the past with remorse, revealed in a number of ways, showing the society hovering in nothingness. ${ }^{(11)}$

The notions of "romanticism" and "romantic vision" have been used most often whenever references to the world presented in Wajda's films have been made. These notions have served to characterise the concept of the hero and his patriotic actions, the historical topics and to justify the intense means of expression by the artist. The term "romanticism" seems to be more suitable because of Wajda's cultural and psychological inclinations which confirm his links with the romantic tradition. Even closer to the artist is his Young Poland, post-romantic vision of his country. This is apparent in his later films filled with bitterness, irredentism, existential grief-- references to the artistic programs of Stefan Żeromski, Stanisław Wyspiański and Jacek Malczewski.

Generally speaking, one may say that Wajda's manner of presenting things uses different styles and poetics and is rooted in historicism, which is a conscious perception of old forms. This leads to the development of a new aesthetic system and the creation of an art ideologically committed and involved in current social and political problems. On the level of communication, the most important are the relations between realism and symbolism, between history and mythology or legends. Such relations are important because they cause tensions in meaning which make Wajda's cinema difficult to interpret within a schematic framework and difficult to classify in generic terms. The tensions also stimulate the attention of the audience and force them to reject traditional perceptive schemes. Thus it seems that this is why Wajda's films have never been perceived indifferently neither in Poland nor abroad.

Wajda offers a rich repertoire of symbols and elements of reality and his aesthetics erase all borders between them. Thus one may always dispute the role played in his films by such elements as white horses (they appear very regularly in his films), national dances, aristocratic mansions, crosses, eye-glasses, refuse-heaps as well as women, iconographic, literary, musical and political motives. Wajda's images are torn between realism and symbolism (e.g. Zbigniew Cybulski plays a young boy living in 1945, while he is dressed behaves like a typical youngster in the 50s) and they also necessitate reading between the lines. These are the elements of the artist's reasoning that for the audience to experience art means getting through to the deep layers of meaning in a never ending way. 
A similar conviction, as well as a Polish artistic tradition, are the reasons why the artist treats history as an emotional category. ${ }^{(12)}$ On the screen he always shows the crucial historical moments of Poland from the literary, or a painterly perspective of a myth or a legend. This is sometimes done through such shocking scenes as the cavalry charge against German tanks in Lotna. The historical visions are always adjusted to the current ideological issues. As a matter of fact, although history has always been his the main topic, Wajda has never made a generically historical film. ${ }^{(13)}$ What he has done is to demystify the traditional vision of history and its official, national or partisan interpretation in order to express the needs of the society, at least of those people who are looking forward to some compensation for the years of silence, violence and repression. Wajda analyses the changes that are taking place in Polish collective awareness shaped by history and culture. However, the political system in the country after the war made it impossible, however, to speak directly. What the artist could do was to look for a way to the truth. This he did by not showing the historical events themselves but by interpreting them.

In other words, when Wajda expresses a major idea in his films, it is surrounded with allusions, ambiguities and implied meanings which offer freedom of interpretation for the audience. Such an artistic device has its advantages and disadvantages. By leaving part of the "truth" beyond the screen pictures and by "implying" things which correspond to the social mood, the artist makes a personal contact with the Polish audience which is able to decipher his intentions. Foreign viewers, on the other hand, perceive the density of expression and look for more hidden meanings (e.g. the universal apocalyptic motive in Canal) which widen the area of interpretation of his films.

On the other hand the lack of emphasis on meaning has often been used by the authorities and Wajda's ideological adversaries as a political tool. They have interpreted his films in a way which could neutralise the their allusions, ambiguities and implied meanings thus using the films for the purposes of the official ideology. It seems that Wajda's system of communication based on such refined mechanism of manipulation made it possible for some interpreters to accuse the artist of flirting with the authorities.

All Wajda's films within the Polish school of cinema had a very wide and strong communicative range till the end of the 90s. Ashes and Diamonds ranks high on all the lists of masterpieces of all times of the Polish and world cinema and has been a source of inspiration for other directors. Zbigniew Cybulski, who played the leading role, became a Polish James Dean, a legend and a symbol of the generation that could not, because of ideological reasons, rationalise and express its protest against the norms and values that determined the everyday life. At the same time the film, which is a synthesis of Polish problems and which reveals the factors that transformed a political conflict into a national one, has always been treated as one of the most artist's most controversial films. It has been "torn apart" both by the critics who are convinced that it is a "cult" piece and by those who are dedicated adversaries of the filmmaker. Probably Wajda himself considers the film as his most important one because he often refers to it in public discussions and in his artistic films.

The major role of Ashes and Diamonds in creating the collective imagination and awareness of the Polish people may be seen in how other directors use the scene in which the former soldiers of the Home Army light glasses of vodka in commemoration of their slain friends. ${ }^{(14)}$ As early as in 1962 this scene was travestied by Wojciech Has in his film Jak być kochana (How to be Loved). The myth was turned into its own contradiction. In the latter picture Cybulski played a heavy drinker looking in bars for an audience willing to listen to his alleged war experiences. In Kontrakt (Contract) by Krzysztof Zanussi, a film made eighteen years later, there is a scene of arson which may be considered a reference to the said scene from Wajda' film. Zanussi, the founder of Polish intellectual cinema, tried to indicate the sham of the socialist culture of lies, lack of positive values and party careerists. Wajda's scene was again remembered in Chce mi się wyć (I Wish I Could Howl - 1989) by Jacek Skalski, a film presenting the gloomy period of the martial law in Poland.

Wajda himself returned to the scene several times and used it as an autobiographic symbol expressing his nostalgic recollections. The significance of the scene stems from the events that occurred in Poland and its national cinema from the quarter of the century, following the premiere of Ashes and Diamonds. Wajda, just like Wojciech Has as early as in 1962, showed the process of the destruction of the myth embodied by Maciek Chełmicki (the hero of Ashes and Diamonds. This was also illustrated in the episode film Love at Twenty (L'amour à vingt ans in which Cybulski played a man recollecting his wartime experiences. The character is considered funny and ridiculous in the eyes of the young people enjoying themselves. Obviously, 
the next generation did not want to have anything to do with the tragedy of the "lost generation" shown by Wajda in his first films. Nevertheless, the director wanted to understand the problems of the young people looking for their own ways of living and used his films to communicate with them. Possibly, this is why he made, as early as in 1961, Niewinni Czarodzieje (The Innocent Sorcerers) in which he said nothing about the problems of his generation.

After the tragic death of Cybulski, Wajda returned to the existential subject of Ashes and Diamonds in Wszystko na sprzedaź (Everything for Sale, 1969) a kind of confession on the screen showing the moods prevailing in Poland at the end of the decade. The scene with the burning glasses was reconstructed as a homage to his dead friend. Despite the appearance of Cybulski's partner from the original film, the scene failed to evoke the emotions of the Polish audiences which the original used to for many decades. Cybulski's successor Daniel Olbrychski became, thanks to Wajda, a new idol of the Polish cinema in the following years playing leading roles in many of Wajda's films, including Brzezina (The Birch Wood), Krajobraz po bitwie (Landscape After a Battle), Wesele (The Wedding), Ziemia obiecana (The Promised Land), Panny z Wilka (The Young Ladies of Wilko).

It was only after the change of the political system in Poland that Wajda could confront his own masterpiece. Pierścionek z ortem w koronie (A Ring With an Eagle in the Crown, 1992) was conceived as a polemics with Ashes and Diamonds. The film repeats the mythic scene showing the tragedy of a young soldier of the Home Army in the first days after the war. The young man has to make up his mind whether or not to accept the new authorities which were not Polish but were brought to the country on Soviet tanks. Piotr Lis was right when he claimed that the filmmaker failed as an artist because he did not stress sufficiently the personal motive of the main character but concentrated instead on the senseless Polish martyrdom, the senseless imperative of devoting one's life for the fatherland. ${ }^{(15)}$ The tragedy of Maciek, in Ashes and Diamonds was much more personal and this is why it was more moving and real. After the premiere of $A$ Ring... the artist also experienced a sort of tragedy. His film was not well received by both critics and the audience. Possibly, the director had a sense of foreboding when he introduced into the film the famous scene, played by young Polish actors, an introduction unjustified by the plot and dramaturgy of the film. It only justifies the author's need to account for the past and to recall "the great period of Polish cinema when there were deep and emotional ties between the artists and the audience."(16)

Wajda's links with the Polish audience weakened several times but usually they strengthened after a couple of years. The viewers were fascinated with the number of masterpieces he made during a difficult period for the country in which he dealt with current problems and the complex of being Polish as well supporting the faith in the sense of manifesting feelings of dignity. Wajda's weakest contacts with the audience may be observed in the period 1961-1968. There are many reasons and one has to remember that the artist realised five feature-films, one TV film and a short film at that time.

The Innocent Sorcerers was made in the trend that dominated in various forms the entire world in that period. In this film about youth deprived of any ideals Wajda was dealing with the same problems as the most distinguished directors abroad. He did not simply follow fashion. The title, a reference to the poetry of Mickiewicz, confirms that he the film's main characters from the perspective of Romanticism. The characters like each other but, playing strip-tease poker, they conceal their feelings under a cover of cynicism and coolness. The film emerged in the best period of the Polish school of cinema and brought it closer to the poetics of other nations. It was awkward for the authorities to whom it showed the failure of the socialist model of education; for the critics it was not like Wajda's other films and for the audience it was provocative and not totally understandable. The innovative, realistic cinematography by Krzysztof Winiewicz, who was working with the director for the first time, was acclaimed as much as Tadeusz Łomnicki's outstanding performance of a man who conceals his feelings behind masks and poses. However, what Wajda failed to do was to start a discussion in Poland about the conflict of generations on the behavioural level. This was achieved by Roman Polański whose Nóź w wodzie (The Knife in the Water, 1962), a much braver film on the same topic, managed to provoke widespread reaction.

Samson (Samson, 1962), an adaptation of a novel by Kazimierz Brandys showed the tragedy of a Jew living in German-occupied Warsaw. It was received with reservations both in Poland and abroad. Again, perfect shots were noticed. This time they were made in an expressionist manner by Jerzy Wójcik. The sensitive 
issue of the Polish-Jewish relationship during the war ignited heated reactions. The casting of the French actor, Serge Merlin, garbled the director's intentions. Wajda was not satisfied with the final result but he treated the subject very seriously as an element of social therapy and returned to it after three decades later in the independent Poland. In Wielki Tydzien (The Holy Week, 1994) he showed the fate of a Jewish girl whom her former lover tried to save from being killed by the Nazis. The reception of the film indicated that for the Poles it is still very difficult to come to terms with the problem.

The period of decline of the Polish school of cinema was not very fortunate for Wajda. The artist was making films abroad then. In 1962 he made Powiatowa Lady Makbet (Sibirska Lady Macbeth) in Yugoslavia (based on the short story by Mikołaj Leskow) and, five years later, in Ava Film Belgrade, an adaptation of Brany raju (The Gates of Heaven) by Jerzy Andrzejewski. Both pictures are considered to be the most unsuccessful ones in all Wajda's work. Although such an opinion may be true of the latter picture, which is about the children's "crusade" at the beginning of the $12^{\text {th }}$ century, it would be totally inadequate, when speaking about The Siberian Lady Macbeth. This film-ballad about a passion that leads to a crime has fascinated the film enthusiasts until today. What they find interesting is the pictorial beauty of the static and classically composed shots that show the Russian country from a century and a half ago. The cold tones of the frames and the stylised performance of the actors rendered the plot improbable. Such an aesthetic exercise did not meet the expectations of the foreign viewers while the Polish audience had to wait many years for an opportunity to watch the film.

Wajda established his contact with the mass audience in quite another way in 1965, after the premiere of Popioty (Ashes), a faithful adaptation of a novel by Stefan Żeromski. The novel is about Polish soldiers who wander with Napoleon's army through distant lands in the hope that one day their fight will bring freedom to their fatherland. ${ }^{(17)}$ The picture created by Wajda contrasts with the official "mild" versions of Polish history, revealing aspects of national sado-masochism. Moreover, it is full of bitterness, cruelty and contradictions. The film was put by the authorities on the school's obligatory "reading list" and, contrary to the artist's intentions, used in political intrigues within the communist party. A kind of war for the ideological significance of Ashes lasted three years. In the most heated discussion in the history of Polish post-war, culture emotions were divided between the hysterical demands of indignant critics and viewers 'to turn Wajda into ashes for his Ashes!' and the gratitude of his supporters for the creation of the national version of The Birth of a Nation. For Wajda's enemies, the film was the biggest historic and artistic swindle in the history of the Polish culture but most of the audience considered it as a profound and honest interpretation of the past events.

The public debate was to a large extent a quasi-discussion guided, even at the school level, by fighting factions in the party. The film itself was seldom treated as a piece of art, a personal expression of the artist or an adaptation of well known literature. Instead, it served the politicians as a pretext in their "fight for the spirit of the nation" (in the words of Jerzy Putrament, an influential party writer) and this is why its autonomic values were diminished and false opinions were mixed up with the truth.

It is no wonder that Wajda, who actively created the legend of the film before its premiere, was silent. He was in no position to influence the discussion in any way. He published, in a major scientific periodical, his own article, which he considered to be his artistic manifesto. ${ }^{(18)}$ In the article he emphasized that he had always considered cinema to be the successor of the long literary and artistic tradition which had made it possible for him to overcome the barrier of obviousness and he defended his freedom to express opinions on any issue. Ashes should be considered as a typical example of "Wajdism", a piece of art full of ambiguous symbols (such as the main character treading a rose and sand covering the corpse of a soldier), quotations from Polish and European painting, surprising events (Prince Poniatowski with a pipe in his mouth charging against the enemy) and very realistic scenes (Polish soldiers raping Spanish nuns, a horse being thrown down a rock).

The film cannot be considered a masterpiece, however, because of its loose structure of narration, excessive ornamentation and exaggerated characters. In the next decade the artist admitted that, paradoxically, his worst film had the largest audience and caused the longest national discussion. On the other hand, judging from the perspective of many years, it seems that it is Wajda who is the winner in the dispute over Ashes because he achieved his ultimate aim. This aim was clearly defined before the premiere of the film when 
Wajda said: "I am not interested in the literature of national agreement. I am interested in Żeromski, full of bitterness and contradictions, real contradictions. (...) the most important is (...) to present our vision on the screen in a convincing, logical and suggestive way so that all those who know the novel would consider it their own not just ours. For those who haven't read the novel the film should be the only version of Ashes". (19)

The dispute over Ashes, during which the artist made frenzied preparations to adapt another novel by Żeromski, the Przedwiosnie (Early-Spring), ${ }^{(20)}$ accelerated or even caused a breakthrough in Wajda's creativity. In the period 1968-1983 he made several great films and some masterpieces which have occupied a permanent place in Polish and international cinema. He also found a wide audience in all spheres of social communication. He provoked viewers to discuss the role of the cinema and other arts but. Most of all, he continued the dialogue with the audience about current problems in his portrayal of real events in Poland and abroad and sometimes even anticipated them.

A new period in Wajda's artistic biography started rather surprisingly with a short science-fiction film for television based on Stanisław Lem's short story Przektadaniec (A Layer Cake) and a confessional feature film Everything for Sale. Both films were made in 1968. The first was soon forgotten but the latter won the highest award of the Ekran weekly. The bravado role of Richard Fox in A Layer Cake was played by an unforgettable comedian, Bogumił Kobiela. One may say that the film was perceived in the same way as Stanisław Lem's fiction. The writer was very popular abroad but extremely undervalued in Poland. Everything Is for Sale was the director's self-therapy and a reflection on his own artistic creativity in the past. Wajda revealed the principles of the poetics that governed his art and created his myth of an unsubmissive artist who always looks for new themes, an artist who is aware of the fact that he will have to face new problems. The film was welcomed by the audience and critics alike. It was analysed very carefully and, together with Federico Fellini's 81/2 claimed to be one of the most interesting achievements of self-reflexive cinema of the $60 \mathrm{~s}$.

Everything for Sale is "a film about a film" and "a film within a film". Such a variant of a constructionin-escutcheon was called a doubly-self reflecting one by Christian Metz. The first term is taken from the language of heraldry where it signifies a small escutcheon placed within a larger one. The small escutcheon reproduces all the details of the large one in a diminished scale. ${ }^{(21)}$ Jurij Łotman, reflecting on Wajda's film observes that "in contemporary films where the montage of coloured with black-and-white film tape is applied, the former is usually connected with the plot of the film while the latter with the reality outside the screen. Wajda consciously complicates this relationship in Everything for Sale. The construction of the film is based on a permanent change in the rank of the picture: the same frame may be related to the reality outside the screen and to the film about this reality" (shots were made by Witold Sobociński). "The viewer is not always warned what he or she is watching-- a piece of reality accidentally caught by the camera or a fragment of a state-of-the-art film." ${ }^{(22)}$ Such a concept was used by Wajda to use the reflections of his own artistic biography (recollections of Wróblewski and Cybulski, quotations from other films, scenes made but never used in other films, etc.) in order to create an allegory of his own cinema. This cinema has always been and will always be torn between realism and symbolism. It has always been and will always be an art, an attempt at catching something that changes permanently.

The self-reflexive technique was used by Wajda again in Pitat $i$ inni (Pilatus and Others, Pilatus und andere ein film für Karfreiteg, made in West Germany, 1972) based on the motifs from The Master and Margarita by Mikhail Bulgakov. The film was addressed to the rebellious youth in the West. Wajda has always been interested in the problem of the myth which, thanks to artists, infiltrates into the reality and even replaces it in social consciousness. The fate of Jeszui Ha-Nocri shown against the background of contemporary Nurnberg was used to express Wajda's conviction (the artist appeared on the screen for the first and only time) that an instrumental use of myths in contemporary culture usually leads to the degradation of values which culture expresses.

One can observe that Wajda was willing to join the fashionable trends in that period. This is best proved by the grotesque feature film Polowanie na muchy (Hunting for Flies, 1969). The film, an adaptation of a short story by Janusz Głowacki was a part of a heated discussion taking place internationally about the feminisation of men and masculinisation of women. Men on the screen couldn't virtually say anything 
and they had nothing interesting to say. This is why a molly-coddled boy was repeating a story-- a very provocative one in Wajda's way of thinking about the nation's history-- about a grandfather who farted in a trench and the Germans fell down. The film had a loyal audience in Poland but it also brought about unexpected reaction. Wajda started to be accused of misogynism and he was reminded that in his earlier pictures he simplified the portrayal of women and connected them with the negative side of the traditional motif of Eros and Thanatos. ${ }^{(23)}$

Such an objection might have seemed well grounded because the premiere of Brzezina (The Birch Wood, 1970) took place soon. The film, adapted from a story by Jarosław Iwaszkiewicz, was a tragedy of unspoken feelings. One of the main characters suffers from tuberculosis but maintains his vitality while another is healthy but, being deserted by his wife, suffers from depression and dislikes women in general. There is one woman who attracts them but they consider her as an ally of death. Thanks to painterly composition (shot by Zygmunt Samosiuk) Wajda could perfectly show the dialectics of states of mind and the processes of increased emotional tension between the main characters. This time his numerous allusions, quotations, symbols and allegories formed a clear series of iconographic-archetypal images which could be placed within the late Young Poland's version of the myth of Eros and Thanatos, a version which identified woman with death. $^{(24)}$

One can say that Wajda has been continuing his game with his audience, a game enriched with new elements, which has sometimes denied the opinions of the artist and placed his film next to or in opposition to his interpretations. Towards the end of the next decade Wajda adapted another short story by Iwaszkiewicz, The Young Ladies of Wilko and made another film, Dyrygent (The Conductor, 1980). In both films women were more positive characters and, much more than men, associated with whatever is beautiful, fascinating and living. In The Young Ladies of Wilko the director included the theme of aging in the narrative framework. In the film, the main character, a man in his middle age, experienced the sufferings of crossing the "shadow line" of age and accepts death. From the very beginning Victor, the main character, has no illusions that the passage of time can be overcome. This is shown by his futile efforts to get closer to five women, portrayed through slightly unrealistic pictures of nature and the inside of an aristocratic little mansion (camera by Edward Kłosiński) and accompanied by the melancholic music of Karol Szymanowski. The main idea of the film was illustrated by Wajda in a documentary Pogoda domu niechaj będzie z Toba (May Serenity of the Home Be with You, 1979).

In The Conductor, one of the principal characters, the husband, has a weaker character than his wife and this is why he loses the respect of an old conductor (John Gielgud) and of the audience. It should be added here that this film enriched Wajda's own image as an artist. His literary, visual and theatrical sensitivity had always been appreciated but his personal perception of music had not been noticed so far. However, this element of his personality was appreciated by Ingmar Bergman. In a message congratulating Wajda on getting European Felix Award he wrote: In The Director, one of your greatest films, the old master shows us that music cannot exist without love. Your music, in each single moment, radiates with the love of your profession, country and people. Simultaneously, you are one of the last who fight for European culture, being faithful to its vision until death." (25)

Wajda's vision of culture has always been based on ideas that supported the values showing the way to true recognition of reality. This is why the artist felt obliged to speak about the criteria that form the basis of positive values. He fought for them, through his films, particularly in the 70s, in the Gierek period when the Polish society was deeply involved in a kind of moral schizophrenia, i.e. the attitudes represented in public life were completely different from those in private lives.

In Krajobraz po bitwie (Landscape after a Battle, 1970) based on the "concentration camp and afterconcentration camp" motifs of Tadeusz Borowski's short stories the director portrayed a Pole, who experienced the cruelties of war. He dreams of a return to his country and to normal life but, being morally and psychologically devastated, feels unable to make decisions and take actions. In order to make a choice he must first understand that, after Auschwitz, the Polish concept of history seen through the focus of old mythical patriotic visions has been an increasingly anachronic one. This is why Wajda showed in a grotesque way the staging of "Grunwald by Matejko" in a DP camp. It lost its historic sense in the scenery of lights and fireworks, filled with the striped clothes of the prisoners and the uniforms of the soldiers. 
Wesele (The Wedding, 1973), a very creative adaptation of Stanisaw Wyspiański's drama from 1900 under the same title is Wajda's second masterpiece, after Ashes and Diamonds. The film includes a scathing criticism of Polish stereotypes. In Wyspiański's drama realistic scenes that take place in a cottage filled with the singing of a wedding party mix with visions that symbolise the bleeding wounds of a society that dreams about independence. Wajda's aesthetically striking adaptation contains wonderful shots made by Wiktor Sobociński correspond with the rich tradition of the iconography of the Polish painting from $19^{\text {th }}$ and $20^{\text {th }}$ centuries. The wedding is a feast during which peasants and intelligentsia fraternise willingly, yet the national idea evoked in a drunk exultation is buried when the people sober up and start quarrelling among themselves. What brings them together again is the cap sheaf's dance bringing back visions of a dancing vicious circle and a romantic polonaise dance, danced by a nation accustomed to waiting only and thus closing the way to freedom. Kazimierz Wyka observes that The Wedding is the most surrealistic piece of art that has ever been created in Poland. He wrote: "it seems that one doesn't have to stress the equivalence of the cottage in Bronowice with 1109, Providence Street from Louis Buñuel's El angel Exterminador". (26)

Ziemia obiecana (The Promised Land, 1975), a free adaptation of a realistic novel by Stanisaw Reymont, is a vision of the hell of early capitalism in $19^{\text {th }}$ century Lodz. All the "urban" sequences were shot in intensive brown and dark-red colours, in the aesthetics of ugliness, rubbish and trash. Fire and diabolic motifs are used to underscore them. Such a vision is contrasted with the images of Polish countryside, full of green grass and shrubbery but, like The Wedding, the artist does not express any hope for a better future of Poland. Contrary to the original text by Reymont, it is a Pole whom Wajda chooses from a group made up of a Pole, a Jew and a German as the most negative character.

The positive model of a man looking for meaning in life is a Conrad-type hero shown in Smuga cienia (The Shadow Line, 1976). This is a story of a man exposed to an extreme situation who keeps his faith and manages to overcome all difficulties. The Shadow Line was a controversial piece of art. On the one hand it was deprived of action (the events take place on a sailing ship at sea in a lull) but on the other hand it proved to be very interesting in terms of aesthetics. The artist showed the major events on the screen in "inverted comas". The unconventional techniques applied (e.g. shots made against the sun, repetition of frames) made it possible to transfer the viewer's attention from the events to the captain's feelings, from the particular meaning of the vision on the screen to a parabolic dimension. ${ }^{(27)}$

The film that moved the Polish and international audience in the 70s was Cztowiek z marmuru (Man of Marble, 1977). It was realised from a scenario written twenty years earlier by Aleksander Ścibor-Rylski. One of the film's main motifs was art being manipulated for ideological reasons. The director managed to put on screen the way in which the ethic and aesthetic concepts interact with outlooks on life and political ideas. The title itself was related to the socialist-realist concept of art and it became a key to understanding the references made to life in Poland in the 1950s and in the two following decades. The hero of the epoch was Mateusz Birkut, a bricklayer, once a shock worker, immortalised in a sculpture by an artist at the service of the communist authorities. Twenty years later Birkut was declared an "enemy of the nation". The main character's ascent and fall from favour and his personal tragedy are seen through the eyes of Agnieszka, who is making a student film about Birkut and his times.

The narrative scheme of a "film in a film" enabled Wajda to make a synthesis of Polish history within the previous twenty years. While Agnieszka is looking for the socialist-realist sculpture of Birkut in the National Museum the viewer can see some paintings hanging on the walls of the museum such as The Land by Ferdynand Ruszczyc, Vicious Circle by Malczewski and Pass me a Brick by Aleksander Kobzdej. The paintings symbolise the changes taking place in the Polish reality and art. Artistic contexts provided comment on the legend of an average, honest Pole, who found himself in a hopeless situation under the pressure of the ideology.

Man of Marble was an innovative and the first fully political Polish film. One can say that it changed radically the general perspective of Polish national cinema. Together with Personel (Personnel, 1975) by Krzysztof Kieślowski, Barwy ochronne (Protective Colours, 1976) by Zanussi, Wajda's film may be counted within the group of films that started the trend of social protest in the Polish cinema, the trend which was later called the cinema of moral unrest ${ }^{(28)}$ by director Janusz Kijowski. This trend originated among young directors, most of whom gathered around Wajda in the "X" Production Group. ${ }^{(29)}$ They included Agnieszka 
Holland, Janusz Kijowski, Felix Falk, Piotr Andrew, Wojciech Marczewski, Barbara Sass and Janusz Zaorski who examined the social consciousness of that time and presented the ills of a society in moral decay.

The young artists carried the technique of "descriptive realism" in film to an extreme. Wajda backed them but he never supported their fundamental formal solutions. His more creative version of the "aesthetics of protest" granted him a separate position in the trend. Nevertheless his two films: The Conductor and Bez Znieczulenia (Rough Treatment, 1978), a story of a party journalist who commits suicide after being hunted down by his colleagues and family, were overshadowed by the films made by the youngest generation of artists.

The TV audience s were more welcoming of Wajda's film documentaries and TV plays made in that period. The artist returned to his favourite motif of the "theatre of death", deeply rooted in history, in his faithful adaptation of Umarla klasa (The Deceased Class, 1977) by Tadeusz Kantor. The play is an amalgamation of scenes and forms from the period of Romanticism, modernism, of Bruno Schulz and Witold Wojtkiewicz painting, mythology, the history of Jews and the Bible. A very original film about art was Zaproszenie do wnętrza (An Invitation to the Interior, 1978) a document showing the collection of Polish folk art in the Warsaw house of a West-German journalist, Ludwig Zimmmerer. The premiere of Noc listopadowa (The November Night, 1978) was a great artistic event. The original drama by Stanisław Wyspiański's, under the same title, showed a national insurrection in 1830 the fall of which was burdened with the anathema of mythology, theatre and the genius loci of Lazienki, the largest park in Warsaw.

Wajda made a beautiful visual "poem of Łazienki". The historical events which take place in the park intertwine (in a literary way-- due to the electronic montage) with the action taking place on Mount Olympus among mythical deities. Another interesting artistic venture was the serial titled $Z$ biegiem lat, z biegiem dni (With the Passage of Years-- With the Passing of Days, 1980), an adaptation of the themes from nine plays written in the years 1874-1915. The director presents Cracow middle class in the period when the cultural and artistic trend of Young Poland was coming into being. On the small screen the artist tried to bring back the mood of Cracow, a city-sanctuary in which a variety of philosophies was being developed, concepts such as "absolute", "naked soul", "lust", "nirvana" as well as philosophy of history and politics that resulted from the impact of Jan Matejko's painting.

In 1980, when the Solidarity Independent Trade Union was created, Wajda was commissioned by his faithful audience, the Gdansk shipyard workers and founders of the trade union, to make Człowiek z Żelaza (Man of Iron, 1980). The dramatic fate of Mateusz Birkut's son took the form of a propaganda film, which proved to be an artistic failure. On the other hand, Wajda shared with his compatriots and viewers abroad his knowledge of contemporary history and its mechanisms. Man of Iron, for which Wajda was granted the Golden Palm at the Festival in Cannes, closed symbolically the period of the cinema of social unrest; it was also a prophetic work. In the film, Wajda applied the "strategy of a fortune-teller" because he doubted the good will of the authorities who signed the social agreement with the striking workers. Unfortunately, his vision materialised some months after the film's premiere when martial law was proclaimed in Poland starting one of the gloomiest periods in its post-war history.

Two years later in France, Wajda made his adaptation of Danton (Danton, 1983) a drama by Stanisława Przybyszewska about the Great French Revolution. The film contains many allusions to the Polish reality. The story of the of a dictatorship that becomes a tyranny, executed in the name of the people, caused much less controversy in Poland than in France. The artist made a clear reference to the recent developments in Poland. He used the character of Danton, an idealised people's tribune, and of Jacques-Louis David (played by Franciszek Starowiejski, a prominent Polish painter), an artist who executes Robespierre's orders (he erased the image of the doomed Danton from his painting). One should remember that at that time a small group of artists-collaborators controlled the Polish cinema within the ideology of "real socialism".

Ten years later, in a press interview, Wajda confessed that "the martial law was the biggest misfortune that happened to Poland. All the contemporary divisions, everything that is confused in our politics and art today is the consequence of the martial law. Poland morally disintegrated at that time and it hasn't been able to unite since then. For me those years were lost. I consider all the films I made after Danton as lost opportunities... I lost my talent to communicate with the audience then." ${ }^{(30)}$ Wajda's sentiment was confirmed by the reaction of critics and audiences to Mitość w Niemczech (Eine Liebe in Deutschland - Love 
in Germany, 1983) an unsuccessful adaptation of a novel by Rolf Hochhuth, a story of a tragic relationship between a German girl and a Polish boy on forced labour in Germany. Wajda's next film, Kronika wypadków mitosnych (The Chronicle of Love Incidents, 1986) is a faithful and splendid adaptation of a novel by Tadeusz Konwicki about the gloomy love of grammar school pupils in their final year in 1939 and which expresses the foreboding of the apocalypses to come. This film, like Wajda's next two works, Biesy (The Possessed, 1988) and Nastazja (Nastasia, 1994), very personal interpretations of Fjodor Dostoevski's fiction were all unwelcome by the audience and critics.

When the political system in Poland changed and the barriers to freedom were removed, Wajda became a senator, which was a natural consequence of all his previous artistic and ideological choices. Until today, however, he has not managed to recover the feeling that he makes films in the name of and for a particular group of the Polish audience. Korczak (Korczak, 1990) is a film about Henryk Goldszmit, an educator and a doctor who was persistent in his efforts to build bridges between the Jews and the Poles and who went to the gas chamber together with his pupils. The film did not cause the reactions that the artist had anticipated and it was, unjustly, attacked by some Jewish circles abroad. The artist felt very deeply the failure of $A$ Ring with an Eagle in the Crown. "... it was just like a car-crash. A disaster...", he said. He would probably say the same about the fate of Wielki Tydzien (The Holy Week).

The artist continues his efforts to find the way to the Polish and foreign audiences. His dilemma is well illustrated in what Wajda said to the press: "It is either Pan Tadeusz or Miss Nobody". The filmmaker wonders whether he will become a "classic" as the author of the screen version of Pan Tadeusz, a romantic epic poem by Adam Mickiewicz, and whether he will gain the trust of young audiences, as the author of the 1996 adaptation of Panna Nikt (Miss Nobody), a popular novel by Tomek Tyzma. Putting on the screen the story of the sad experiences of teenage girls was a risky undertaking. The film may be considered an exceptional one when compared with the unsatisfactory output of the contemporary Polish cinema but certainly it did not strike a chord with the young generation.

The artist remained. persistent, however. Three year later he brought onto the cinema screens the adaptation of the "Polish idiom", a masterpiece of romantic poetry-- Pan Tadeusz. When the film was in production, Wajda said: "I am aware of the fact that Pan Tadeusz was not written to be filmed by me[...] When I see all the billboards in foreign languages and when I know that 90 per cent of films watched by the Polish people are spoken in English I am convinced that it is the right time for Pan Tadeusz [...] I want to make a single scene that would give the pretext to the ending. I would like to show a picture in which Adam Mickiewicz-this will be a mysterious character, who is clearly seen on the screen-- reads Pan Tadeusz to his friends in Paris [...] After a closer look it will turn out that his listeners are the aged heroes of the poem. I think that Mickiewicz, when he was writing his masterpiece in Paris must have portrayed people from his own environment. It seems to me that such a method may help the contemporary viewers to realise where we are at the moment [...] It is the beauty of Pan Tadeusz that moves us so deeply. I expect that this is the place where I am prepared to meet Mickiewicz's poem. ${ }^{(31)}$

Pan Tadeusz has been one of the most expensive Polish films and a great box-office success in its country. It is generally believed that Wajda, aged 71, directed, in the tradition of Romanticism most close to him, the best kind of poetry. He gave creative opportunities to a large group of popular actors and increased his repertoire of images of supreme quality. What he failed to do was to show Mickiewicz as a mysterious person, since the poet seems to be clearly seen on the screen. Neither did he begin to establish a permanent contact with the audience. He is aware of the fact that the domestic success of his latest film imposes the duty of an even greater effort upon him. During the press conference organised on the occasion of being granted an Academy Award (January 26, 2000) he told journalists: "Those who give Oscar Awards for a lifetime of creativity always wait until the person is old enough to be awarded the prize. They do not know, however, that I am just about to start [...]. The biggest difficulty for a film director is to discover the main character of a film to be made. The heroes of our political period have always been young people, handsome men, preferably cadets. In the films to be made the main character should be a woman. It was Kieślowski who introduced female heroes into Polish cinema, he was a prophet artist who gave us an example of 'our way to victory'" (a line from the Polish national anthem). Wajda will no doubt continue to fulfill his duties towards the audience, by looking for ways to communicate with them. 
(Text and all quotations used in the text translated by Piotr Mamet)

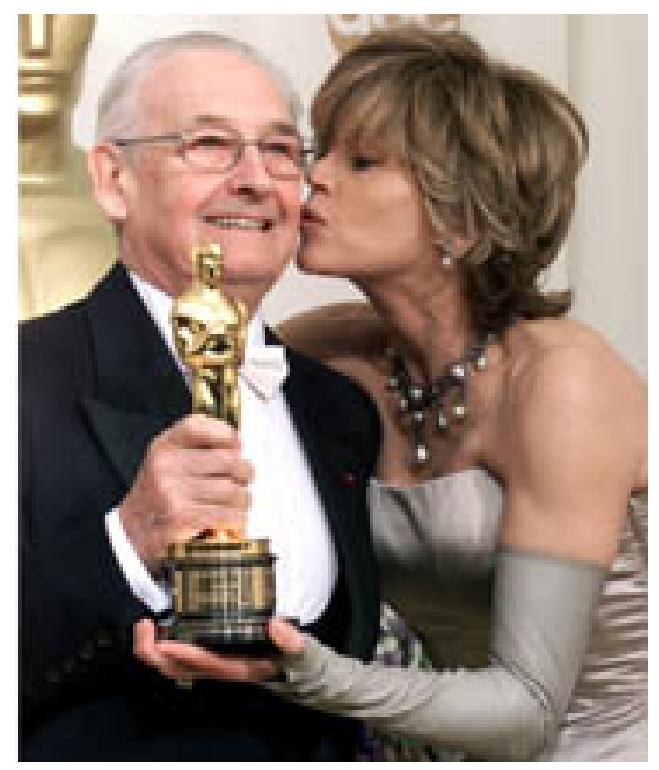

Figure 1: Director Andrzej Wajda receiving Honorary Oscar (2000)

\section{Notes}

1. T. Sobolewski, "Moment deziluzji. Spotkania z Andrzejem Wajdą." ("A moment of desilusion. Meetings with Andrzej Wajda"), Kino, 1991, no.7, p.6.

2. In the history of Polish literature, the years from 1890 to 1918 are called the period of Young Poland. It was a time of intellectual crisis and of fin de siècle sophistication and disillusionment in the cultural world. (In Encarta Encyclopedia.) http://encarta.msn.com/index/conciseindex/65/0657E000.htm. 4 April 2000.

3. Young Poland, a period from 1890 till 1918 before Poland won Independence (1918). In the history of art it is dominated by the trends typical for the European modernism. The models of Young Poland's art and culture are defined and discussed by K.Wyka in: "Charakterystyka okresu Młodej Polski," w: Obraz literatury Polskiej XIX i XX wieku. Literatura Okresu Młodej Polski ("The Characteristics of the Young Poland Period." in: The Picture of the Polish Literature in the 19th and 20th Centuries. The Literature of the Young Poland Period. Vol. 1, Warsaw 1968, pp.36-37.

4. I wrote about the ideological relationships of authorial strategies dominating in the Polish cinema in an article: "Cinema Under Political Pressure: A Brief Outline of Autorial Roles in Polish Post-War Feature-Film 1945-1995." Kinema (Waterloo) no.4, Fall 1995, pp. 32-48.

5. See, e.g.: K. Eder, K. Kreimer, M. Ratscheva, B. Thienhaus, Andrzej Wajda, München-Wien 1980, passim.

6. T. Lubelski, Strategie autorskie w polskim filmie fabularnym lat 1945-1961 (Authorial Strategies in Polish Feature Film 1945-1961), Kraków 1992, pp. 154-183.

7. Op.cit. p. 144.

8. This aspect of Wajda's film art has always fascinated film enthusiasts and critics. Especially interesting are the researches that stress the relationship between Wajda's films and painting. Compare, e.g.: T. Miczka, Inspiracje plastyczne w twórczości filmowej i telewizyjnej Andrzeja Wajdy (Fine-art inspirations in Wajda' film and TV production), Katowice 1987. A. Grunert, Film Malerei. Von Matejko zu Wajda: Eine 
Gebrauchsanweisung, "Filmfaust 88", Aug.-Sept. 1998, pp. 12-15; the same author: Andrzej Wajda, Visions de la Pologne - peinture et cinéma, Paris.

9. In the period 1959-1963 the director staged five dramas: The Hat Full of Rain by M.V. Gazzo, Hamlet by Shakespeare, Demons by J.Whitining and The Wedding by S. Wyspiaski. His theatrical output has been desicussed by M. Karpiski in his book Andrzej Wajda - teatr (Andrzej Wajda - Theatre), Warszawa 1980.

10. A. Wajda, "Teatr i kino reżyseruję tak samo..." ("I Direct Film and Theatre in the Same Way...") Kultura 1972 , no.2, p.5.

11. P. Pitiot, Cinéma de mort. Esquisse d'un baroque cinématographique. Fribourg 1972, p.16.

12. A closer definition of the category may be found in the article by Z.Ostrowska-Kębłowska, "Historyzm w architekturze XIX wieku. (Próby wyjśaniania), w: Interpretacja dzieła sztuki. Studia, dyskusje," ("Historism in the Architecture of the 19th Century (An Attempt at an Explanation") in: Interpreting a Piece of Art, Studies, Discussions, ed. J. Kbowski, Pozna 1976, pp.77-99.

13. The reconstruction of Wajda's film historiography has been recently done by E. Nurczyńska-Fidelska in an article "Romanticism and History. "On the creative Output of Andrzej Wajda" in: Polish Cinema in Ten Takes. Ed. E. Nurczyńska-Fidelska, Z. Batko, "Bulletin de las Société et des Lettres de ód" 1995, vol. 45, Serie: Recherches sur les Arts, vol.6, pp.7-20.

14. This issue has been presented in a detailed way by M. Przylipiak in: "Było kiedyś tylu fajnych chłopców i dziewcząt?" ("Have there Ever Been So Many Nice Boys and Girls ?"). Kino 1996, no.3, pp.9-11.

15. P. Lis, "Wajda przeciw Wajdzie" ("Wajda against Wajda"), Kino 1993, no.8, pp.34-35.

16. M. Przylipiak, op.cit., p.11.

17. See: T. Miczka, Tekst jako "ofiara" kontekstu. Spór o "Popioły" Andrzeja Wajdy? w: Syndrom Konformizmu? (Text as a "Victim" of Context? in: The Syndrom of Conformism? Polish Cinema of the 60s). Ed. T. Miczka, A. Madej, Katowice 1994, pp. 147-165.

18. A. Wajda "Popioły - przykład mojej estetyki filmowej." ("Ashes - an example of my film aesthetics") Studia Estetyczne 1965, Vol. 2 pp. 122-127. Printed in: Kwartalnik Filmowy, no. 4, 1966.

19. "Andrzej Wajda o Popiołach - przed premiera.." ("Andrzej Wajda about the Ashes - before the premiere"), Kino 1965, no. 1, p. 33.

20. Wajda is speaking about his not realised films in a most detailed way to S. Janicki. See Film na Świecie 1986, no 329-330. See also "Stenogram z posiedzenia Komisji Ocen Scenariuszy z dnia 18 stycznia 1966 roku" ("Minutes of the Proceedings of the Commission for the Evaluation of Scenarios, January 18, 1966") (re: The Early Spring film)., Iluzjon 1990, no. 3-4, pp. 34-41.

21. Ch. Metz, "Mirror Construction in Fellini's 8 1/2," in: A Semiotics of the Cinema: Film Language, New York 1974, pp. 228-234.

22. J. Łotman, Semiotyka filmu (Semiotics of Film), translated by J. Faryno, T. Miczka, Warszawa 1983, p. 62.

23. See: J.Pyszny, "Kobieta w filmach szkoły polskiej, w: Polska szkoła filmowa. Poetyka i tradycja" ("Woman in the films of the Polish School of Cinema," in: The Polish School of Cinema, Poetica and Tradition), ed. J. Trzynadlowski, Wrocaw 1976, pp. 91-101.

24. I support this interpretative thesis in a more detailed way in an article "Andrzej Wajda - The Birch Wood," Moveast (Budapest) 1991, no.1, pp.149-161.

25. Quoted after: "Spotkałem wielu ludzi - mówi Andrzej Wajda" ("I met a number of people - Andrzej Wajda Speaks"), Kino 1991, no. 4, p. 5.

26. K. Wyka, Nowe i dawne wędrówki po tematach (New and Old Wanderings Over the Topics).Warszawa 
1978, p.143.

27. I described this unconventional method in an article "Literature, Painting and Film in Andrzej Wajda's The Shadow Line", in: Conrad on Film, ed. by G. M. Moore, Cambridge 1997, pp. 135-150.

28. See, e.g.: "L'Uomo di marmo" e il ruolo de Wajda, in: S.D'Arbela, Nuovo Cinema Polacco. L'inquietudine e lo schermo. Da wajda e Zanussi al quarto cinema, Roma 1981, pp. 25-32.

29. See: W. Wartenstein, Zespót filmowy "X" (Film Group "X"), Warsaw 1991.

30. "Wajda: albo Pana Tadeusza albo Pannę Nikt ("Either Sir Tadeusz or Miss Nobody), Kino 1995, no.2, p.9.

31. "Jeszcze raz zaczynam." ("I Am Starting from the Beginning Again") An interview with A. Wajda of K. Bielas "Magazyn" a supplement to Gazeta Wyborcza 1998, July 3-4, pp. 22-23.

\section{Author Information}

Tadeusz MICZKA is Director of the Institute of Cultural Studies, Faculty of Philology, University of Silesia, Katowice, Poland. His main fields of research are history of the Polish, Italian, and Central and East European cinemas, film theory, and issues related to modern media, including neo-television, virtual reality, audio-visual communication. Prof. Miczka is the author of many publications on the history and theory of cinema, methodology of education and of comparative researches on contemporary culture. 